10.4079/pp.v18io.9358

\title{
The Unauthorized Student Population: Examining the Alternatives
}

\author{
By Jennifer Javier
}

Unauthorized students face significant barriers to pursuing a higher education due to their legal status. These challenges include the fear of revealing their status, the inability to work legally, and federal and state laws that increase the cost of tuition. Obtaining a higher education and legal status would allow these individuals to earn higher incomes, lead healthier lives, and fully contribute to their communities. This paper examines alternatives that address the status of the unauthorized population and, among these options, recommends the best approach to their plight.

\section{Introduction}

"Once, when I was seven, I fell asleep in Michoacan (Mexico) and woke in Boyle Heights. No joke," wrote Erick Huerta, a journalism student attending college in Los Angeles. Though Erick was born in Mexico, his parents came to the United States, lured by the American Dream (Huerta 2010). Unauthorized students like Erick were brought to America by their parents at a young age and face significant barriers, especially in obtaining a higher education. Despite calling the United States their home, these students cannot contribute their skills and talents to society because of their legal status.

While the unauthorized student population is allowed to attend public primary and secondary schools, a significant number do not pursue a higher degree.
Some students are reluctant to apply for college out of fear of being deported. Others may be discouraged because, whether or not they have a college degree, they cannot work legally. Moreover, federal and state laws make tuition unaffordable, and their parents' low-wage jobs make it difficult for these individuals and their families to pay for a higher education. Lowskilled and low-wage jobs will not sustain this population or the nation's workforce as the country's economy becomes increasingly dependent on immigrants. The current climate makes it necessary to analyze options that address the educational and legal status of this population.

The purpose of this paper is to examine the unauthorized student population and their access to education. First, this paper will identify the financial and legal barriers these students encounter in obtaining a higher education and the implications of this problem. Next, an analysis of three possible alternatives to address the legal status of the unauthorized student population will be conducted. Based on this examination, the paper will conclude with identifying the best strategy to tackle this problem.

\section{The Unauthorized Population}

Unauthorized immigrants are foreign citizens residing in the United States illegally, a term that refers to two separate categories of immigrants: those who enter the country without approval of the immi- 
gration process, and those who violate the terms of a temporary admission without obtaining permanent residency or temporary protection from removal. According to the Pew Hispanic Center, there are an estimated $\mathbf{1 1 . 1}$ million unauthorized immigrants in the United States (Passel and Cohn 2010). The regional sources of this population include Asia, Central America, South America, the Caribbean, and the Middle East. The majority of this population ( 7 million) is from Mexico. About half of the nation's unauthorized immigrants live in just four states: California, Texas, Florida, and New York (Passel and Cohn 2009).

Unauthorized immigrants make up a significant share of the US labor market. The nation's labor force of almost 155 million people includes an estimated 7.8 million unauthorized immigrants (Passel and Cohn 2010). According to the Migration Policy Institute, the driving factors of unauthorized immigration include the US economy's need for low-skilled labor, the limited legal flows for low-skilled workers in the United States, and the higher earning potential in the United States compared to their countries of origin (Hanson 2009). As a result, unauthorized immigrant workers have been an important source of low-skilled labor supply to the US economy.

Children of unauthorized immigrants are in a unique situation. According to the Pew Hispanic Center, of the 11.1 million unauthorized immigrants in the United States, 1.1 million are children (Passel and Cohn 2010). While parents come to this country looking for work, their children must deal with the consequences of a decision that was not their own. Without a means to obtain legal status, unauthorized children have limited opportunities, are unable to receive proper work authorization, and ultimately have no other option than to work illegally. Furthermore, because they were raised in the United States, they have little connection to their native countries and returning is not a viable option.

\section{Education Hurdles}

While unauthorized immigrants can attend public schools through high school, they encounter significant challenges in pursuing a higher education. Since 1982, unauthorized children may not be excluded from state-funded public primary and secondary schools because of their immigration status (Plyler v. Doe 1982). The Congressional Research Services states that every year, 80,000 unauthorized children turn 18 years old; an estimated 65,000, or 81 percent, of those children are expected to graduate from high school (Bruno 2010). Yet, far fewer unauthorized children attend or complete college. Of the unauthorized population ages 18 to 24 that have graduated high school, 26 percent have some college or a college degree. The comparable figure for US-born residents is 58 percent (see Figure 1). Recent research also suggests that unauthorized students face challenges during school; these students perform well in their first two years of college compared to US citizens, yet are less likely to graduate within four and six years than US citizens (Conger and Chellman 2011). These discrepancies between the unauthorized population and US citizens can be explained by the substantial difficulties the unauthorized encounter in pursuing a higher education.

\section{Legal Status}

Although some universities have a "don't ask, don't tell" admission policy toward unauthorized students, some students still do not enroll for fear of revealing their status (Lee 2006). Because of their illegal status, students face the possibility of being deported on a daily basis (8 U.S.C. $\$ 1227$ 2010). In addition, federal law currently stipulates that it is unlawful to hire or recruit unauthorized aliens for employment (8 U.S.C. $§ 1324 a$ 2010). Consequently, if one does not have work authorization and a college education will not increase one's ability to work legally, then college may be avoided altogether. 


\section{Affordability \\ Unauthorized students are less} likely to obtain a higher education because of the cost of tuition. Unauthorized families are more likely to rely on low-wage jobs in agriculture, construction, and hospitality services, preventing them from contributing financially to their child's education (Passel and Cohn 2009). These low-wage jobs explain why the median household income for unauthorized immigrants is about $\$ 35,000$ a year (see Figure 2). As a result, college tuition is becoming increasingly out of reach for low-income families. Low incomes make it difficult for unauthorized families to contribute to their children's education as tuition and fees at public four-year universities are expensive; published in-state tuition and fees at public four-year institutions averaged $\$ 7,605$ and $\$ 27,293$ for private schools in the 2010-11 school year (College Board 2010). In the last decade, tuition rates have risen at an average annual rate of 4.9 percent per year beyond general inflation. Low household incomes combined with high tuition costs make it difficult for unauthorized students to afford higher education.

Federal and state laws also create higher costs for unauthorized students. They may not be able to secure funding for higher education because their unauthorized status disqualifies them from receiving financial aid under the Higher Education Act of 1965 (Bruno 2010). In addition, a provision enacted in 1996 as part of the Illegal Immigration Reform and Immigrant Responsibility Act (IIRIRA) discourages states and localities from granting the unauthorized population certain higher education benefits. Section 505 of IIRIRA mandates that unauthorized aliens:

shall not be eligible on the basis of residence within a State (or a politi-

Figure 1: Educational Attainment by Nativity and Status for Ages 18 to 24, 2008.

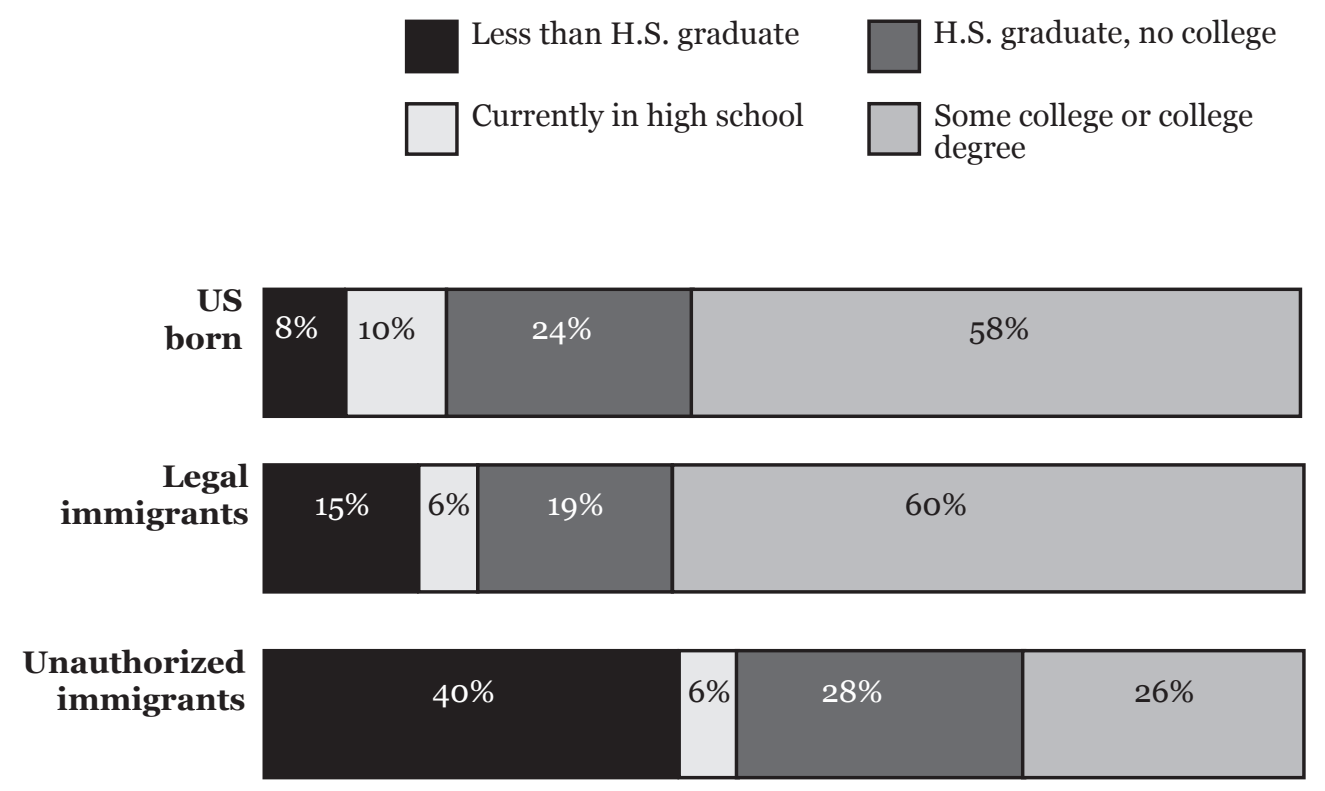

Source: Pew Hispanic Center, Passel and Cohn 2008. 
cal subdivision) for any postsecondary education benefit unless a citizen or national of the United States is eligible for such a benefit (in no less an amount, duration, and scope) without regard to whether the citizen or national is such a resident (8 U.S.C. $\S 1623)$.

While there is neither report language nor agency regulations available to provide guidance, this provision appears to be designed to prevent states from offering unauthorized students in-state tuition at public universities (Feder 2010). As a result, unauthorized students are subject to higher tuition rates. For the 2009-10 school year, out-of-state tuition and fees at public four-year colleges and universities averaged $\$ 19,595$, an amount beyond the budget of the average unauthorized student (College Board 2010). Private schools are not subject to IIRIRA because the law only applies to public benefits.

The impact of IIRIRA on the unauthorized college-aged population is significant. According to the National Conference of State Legislatures, IIRIRA has affected up to 65,000 unauthorized students that graduated from high school annually since the law's passage in 1996 (2010). To date, this amounts to nearly 1 million unauthorized students impacted by the law. It is important to note that 11 states have subsequently enacted laws granting in-state tuition to unauthorized students if they graduate from state high schools, have two or three years of residence in the state, apply to a state university, and sign an affidavit promising to seek legal immigration status (Morse and Bimbach 2010). Despite these laws, the majority of states still charge out-of-state tuition rates.

\section{Implications}

Because of the challenges surrounding their legal status, a limited number of unauthorized students attend college. In 2006, only 50,000 out of the 360,000 possible unauthorized high school graduates - less than 14 percent - were enrolled in universities (Migration Policy Institute 2006). Even those who overcome these obstacles and receive

Figure 2: Median Household Income by Status and Time in United States, 2007.

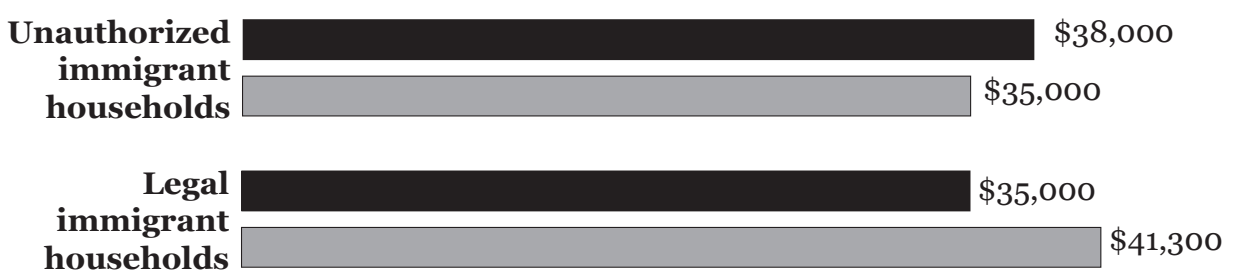

\section{US-born households} $\$ 50,000$

Note: Incomes rounded to the nearest 100 dollars.

Source: Pew Hispanic Center, Passel and Cohn 2008. 
a college degree generally cannot obtain meaningful employment without legal work authorization.

It is relevant to acknowledge that some do not view the plight of the unauthorized population in a favorable light. Critics argue that assisting the unauthorized student population provides incentives to immigrate illegally to the United States, rewarding these students for breaking the law. Yet foreign workers are not motivated by benefits; illegal immigration occurs because these individuals can earn much more in the United States than they can at home. For example, an urban male from Mexico with secondary education can increase his income 2.5 times by simply moving to the United States. This is the case even after controlling for cost-of-living differences between the two countries. The income gain from migration is the result of international differences in labor productivity; US labor is compensated at a much higher rate for the same work done in Mexico. Foreign workers also meet a demand in the United States for low-skilled labor in agriculture, construction, food processing, building cleaning, and maintenance (Hanson 2009). Furthermore, critics argue that any assistance to these students takes away enrollment slots from legal citizens and legal immigrants (National Conference of State Legislatures 2010). In contrast to these assertions, research suggests that subsidized tuition has a negligible effect on the college enrollment of US citizens, including minority groups, and may modestly increase the number of citizens pursuing a higher education (Kaushal 2008; Flores 2010).

Such criticisms do not overshadow the implications of the unauthorized status of these students. Without legal status, these individuals may be pushed into the underground economy and isolated from mainstream American society. Numbers support the economic value of an education; average earnings increase at each educational level from comple- tion of some high school ( $\$ 18,948$ a year) through the completion of a bachelor's degree ( $\$ 53,442$ a year) and higher (US Census Bureau 2010). Not only does education improve the economic status of an individual, it also has the potential to benefit the surrounding community. Besides increased earnings, studies have found that more educated people commit fewer crimes, vote more, and are healthier (Cutler and Lleras-Muney 2006; Dee 2004; Lochner et al. 2004).

It is in the nation's economic selfinterest that the younger population succeeds in school and in the labor market. Researchers at the National Center on Immigrant Integration Policy argue that the baby boom generation is retiring, the growth of native-born labor force is stalling, and the global competition for labor is heightening, emphasizing a need for an educated workforce from other countries (Fix et al. 2008). In order for the United States to maintain its standing in the global economy, investing in the immigrant population is key. It is estimated that immigrants and their children are expected to account for all workforce growth between 2010 and 2032 (Lowell et al. 2006). In the healthcare system, for example, the United States is facing a personnel shortage. Immigrants comprise more than one-quarter of all physicians and about one-fifth of all nursing, psychiatric, and home health aides. The Bureau of Labor Statistics predicts significant numbers of job openings in the health care occupations where most foreign-born health care workers are employed (Ewing 2009). The US Department of Health and Human Services also found that the demand for physicians will increase, and there will be a shortage that the native born population will not be able to fill (Ewing 2009). Currently, an entire class of people cannot contribute to the economy beyond lowskilled jobs at best. Addressing the plight of unauthorized students and the barriers they encounter in obtaining a higher education has the potential to help fill such 
gaps in the nation's workforce.

Failure to address the unauthorized student population will be very costly for local, state, and federal governments. For nearly thirty years, state and local governments were required to provide public primary and secondary education to unauthorized children. The education costs to state and local governments range in the tens of millions to billions, depending on the size of the unauthorized population in the state (CBO 2007a). Because this population cannot contribute legally to the economy upon graduation, these governments are losing on their investment. In addition, the costs to the federal government are high because enforcement of immigration law falls under its jurisdiction. While the cost to implement other federal policies, including the Higher Education Act of 1965 and IIRIRA, are low, immigration enforcement during the mid-20oos cost $\$ 10$ to $\$ 15$ billion a year. Despite high enforcement costs, 500,000 unauthorized immigrants enter the country annually and an estimated 7.8 million are working illegally (Hanson 2009; Passel and Cohn 2010). Given the potential benefits of integrating this population and the high costs across all levels of government to maintain the current situation, the plight of the unauthorized students must be addressed.

\section{Alternatives}

The following discussion will describe three strategies to address the unauthorized student population and its barriers to obtaining a higher education. The first alternative is the Development, Relief and Education for Alien Minors (DREAM) Act (H.R. 5281). The second option is the Comprehensive Immigration Reform for America's Security and Prosperity (CIR ASAP) Act of 2009 (H.R. 4321). The last alternative focuses on implementing programs that serve the unauthorized student population at the state level. Before examining these strategies, it is necessary to describe the criteria that will be used to evaluate each option.
Effectiveness examines the alternative's ability to address the legal status of the unauthorized student population and the problems it encounters in obtaining a higher education. This criterion will examine three aspects of the issue:

1. Increase the number of unauthorized students that can access federal financial aid and in-state tuition;

2. Increase the number of unauthorized students graduating from higher education institutions; and

3. Allow access to the workforce with proper work authorization (Bruno 2010).

Cost is based on the cost borne by the government to implement each policy alternative (Irwin 2003). More specifically, this includes the costs to the federal, state, and local governments.

Administrative feasibility refers to the ease of implementation for each policy (Bardach 2009). This encompasses the administration, staff, and agency capacity of federal, state, and local bureaucratic systems to execute these policy alternatives.

Political feasibility assesses the degree to which federal elected officials and the public will support and implement each policy (Griswold 2010). This involves examining the will of the President, House and Senate Judiciary Committees (which have jurisdiction over immigration policy), and congressional leaders to support these policies.

Sustainability refers to the longterm ability of each alternative to address the legal status of the unauthorized immigrant student population in the United States and future populations entering the country (Bardach 2009). It is necessary to examine if these policies are viable or a short-term remedy to this complex problem.

Alternative 1: Development, Relief and Education for Alien Minors (DREAM) Act This section will examine the most recent version of the DREAM Act, which 
passed in the House of Representatives in December 2010 but failed in the Senate. The DREAM Act would have allowed unauthorized students to apply for conditional nonimmigrant status. In order to be eligible, they would have had to meet the following requirements: be physically present in the United States for a continuous period of five years preceding the date of enactment; not yet reached age 16 at the time of initial entry; possess good moral character since the date of entry; be under the age of 30 on the date of enactment of this act; and be admitted to a higher education institution or earned a high school diploma or equivalent.

As conditional nonimmigrants, these individuals would be eligible for work authorization (Library of Congress 2010a). Establishing permanent residency would be dependent upon the applicant meeting certain requirements such as having attained a college degree, completed at least two years of a bachelor's or higher degree program in the United States, or served in the Armed Forces for two years (Bruno 2010). Conditional nonimmigrants and lawful permanent residents under this act would also be eligible for federal financial aid, including student loans, federal work-study, and tuition relief services (Library of Congress 2010a). The following details how the DREAM Act fared under each criterion:

\section{Effectiveness}

The DREAM Act will increase the number of students that can access federal financial aid by making both conditional nonimmigrants and permanent residents under this act eligible for aid. However, the bill does not repeal Section 505 of IIRIRA, a stipulation of an earlier version of the bill (Library of Congress 2010b). Additionally, the bill does not address the unauthorized population's access to in-state tuition. As conditional nonimmigrants and permanent residents, students will also be allowed to work legally during school and upon graduation. Despite hav- ing access to federal student loans and the labor market, there are other barriers such as English proficiency, income, parental status, and labor force participation that impact an unauthorized individual's ability to attend and complete postsecondary education (Batalova and McHugh 2010). Taking into account these challenges, the DREAM Act mitigates some barriers for this population to pursue a higher education and still has the potential to increase the number of those graduating from college.

\section{Cost}

The cost to state governments to implement the policy would be low. Some states have existing laws granting in-state tuition to unauthorized students while other states may continue to charge this population out-of-state rates. The states that choose to provide in-state tuition already have existing structures to implement the policy. Furthermore, not all of the 360,000 eligible for college would enroll, and those that choose to attend will not place a significant cost burden on states because they would be able to work legally and will be eligible for student loans. Furthermore, local and state governments will receive a return on their investment from educating this population because they will become higher income, tax-paying members in these communities.

The cost to the federal government would be in the form of administrative costs. The bill states that the US Department of Homeland Security (DHS) will collect a surcharge of $\$ 525$ per application in addition to all application fees imposed for the purpose of recovering the full costs of providing adjudication and processing services. This is significant because current permanent resident application fees range from $\$ 635$ to $\$ 1,000$ (US CIS 2011). Thus, the costs to the federal government would be low because the fees and additional revenue from the surcharge would cover the administrative costs. 
In addition, the Congressional Budget Office (CBO) developed a cost estimate of the bill and its financial impact over time. The increase of authorized workers would affect individual and corporate income taxes and social insurance taxes, ultimately increasing revenues by $\$ 1.7$ billion over ten years. CBO also estimates that the bill would decrease net direct spending by $\$ 500$ million over the 2011-2020 period due to changes in spending for refundable tax credits, Social Security, Medicare, student loans, and DHS. Further, CBO estimates that the effects on discretionary spending would be small. Ultimately, CBO projects that deficits would be reduced by $\$ 2.2$ billion over the 2011-2020 period. It is necessary to note that CBO (2010) states that the conversion of conditional nonimmigrants to legal permanent resident status after 2020 would lead to increases in spending for the federal health insurance exchanges, Medicaid, and the Supplemental Nutrition Assistance Program. However, an amount was not specified.

\section{Administrative Feasibility}

The administrative feasibility of the bill would be manageable. If states choose to provide in-state tuition benefits to unauthorized students, there are existing structures and application systems already in place. Also, the bill would add a new category under permanent residency status and require expedited processing within Citizenship and Immigration Services (CIS), the federal agency within DHS that processes immigration applications. From CIS's perspective, the bill would require employee training and a quick turnaround time to adjudicate the applications of the 619,000 unauthorized students immediately eligible for legal permanent residence or conditional nonimmigrant status under the bill (Migration Policy Institute 2010). CIS may need to hire additional adjudication officers and staff to handle the increase in workload, but the bill's fees and surcharges are designed to address this increase. While there is a concern about the timeliness of processing, CIS has the capacity to handle the influx of applications. For instance, the agency processed nearly 6 million applications in 2009, but in 2007 CIS adjudicated 7.5 million applications, demonstrating the agency's ability to process an increase in the number of applications (USCIS Ombudsman 2008, 2009). Thus, the agency can accommodate the projected increase in workload should the DREAM Act become law.

\section{Political Feasibility}

While the DREAM Act passed in the House of Representatives, the measure failed to gain enough votes in the Senate at the end of the lame duck session of the 111th Congress (Vendantum 2010). President Obama has maintained that he will continue to push for the legislation and that broader immigration reform should be pursued in the 112th Congress (Associated Press 2010). It is expected that the 112th Congress will not bring the measure up for a vote because the Republicans have a majority in the House. Representative Lamar Smith (R-TX), Chairman of the House Judiciary Committee, and Representative Elton Gallegly (R-CA), Chairman of the Subcommittee on Immigration Policy and Enforcement, both voted against the DREAM Act, and both are expected to press for increased border security and enforcement in the 112th Congress (US House of Representatives 2010). They have admitted that immigration reform is a priority, but the DREAM Act would not be on their list (Emery 2010). Given these factors, the current political environment makes it difficult for this bill to be seriously considered in Congress.

\section{Sustainability}

The DREAM Act provides a path to permanent residency and access to higher education funding for the unauthorized student population. However, the bill would only cover those who have been in 
the United States five years preceding the date of enactment and those under the age of 30 (Library of Congress 2010a). Groups that fall outside these parameters would be excluded from the bill, and another class of unauthorized students would be created. The bill also does not address the fact that unauthorized immigrants are still entering the country with their children, although at a lesser rate due to the recession (Passel and Cohn 2010). In essence, the DREAM Act is a temporary band-aid to a more complex problem. In the short term, the DREAM Act has the potential to improve the lives for most of the unauthorized student population, yet others will be excluded in the long run.

Alternative 2: Comprehensive Immigration ReForm For America's SECURITy and ProsPERITY ACT OF 2009 (CIR ASAP ACT)

While the CIR ASAP Act did not move from the House Subcommittee on Immigration, Citizenship, Refugees, Border Security, and International Law during the 111th Congress, it is the most recent version of a comprehensive bill with a significant number of co-sponsors. The main provisions include: enhancing border security and immigration enforcement; creating an employment verification system for employers to verify work authorization of new hires; reducing long backlogs in family and employment immigrant and nonimmigrant visa processing; creating a legalization program for qualified undocumented immigrants and their spouses and children; and creating an independent federal Commission on Immigration and Labor Markets (Immigration Policy Center 2009). This extensive bill includes the legalization of individuals brought into the United States as children; however, the bill's legalization program does not have an age restriction like the DREAM Act (Library of Congress 2010c).

\section{Effectiveness}

While the CIR ASAP Act integrates the legalization of unauthorized children brought into the United States into the bill, one important difference is that this bill repeals Section 505 of IIRIRA. This would allow states to determine their own in-state residency requirements pertaining to higher education and, as a result, more students may have access to in-state tuition (Library of Congress 2010c). Because of this, the CIR ASAP Act, as it is currently written, is considered more effective than the DREAM Act.

\section{Cost}

While the CBO has not conducted a cost estimate of this legislation, it is helpful to look at the cost estimate of the last immigration reform bill, the Comprehensive Immigration Reform Act of 2007 (S. 1348), as a basis of comparison. The CBO estimated that changes in direct spending and revenues from the legislation would reduce deficits by $\$ 5$ billion over the first five years and by $\$ 26$ billion over the 10-year period. However, discretionary spending is key to implementing the legislation, which is estimated to increase the deficit of about $\$ 15$ billion over the next five years (CBO 2007b). While the CIR ASAP Act is a different bill, it contains most of the provisions in the Comprehensive Immigration Reform Act and has numerous additions, including creating Border Communities Liaison Offices, establishing taskforces and commissions, creating programs to prevent $\mathrm{H}-1 \mathrm{~B}$ fraud, increasing the US Department of Labor's authority, and creating grant programs to improve integration (Migration Policy Institute 2009). Therefore, we can expect the implementation costs of the CIR ASAP Act to be very high for the federal government.

CBO also identified intergovernmental mandates under the Comprehensive Immigration Reform Act, which are also included in the CIR ASAP Act. Some of these mandates include preempting certain state and local authority, requiring local governments to verify work eligibility, and imposing new requirements on 
governments should they seek to hire certain foreign workers. According to CBO's analysis, the cost to comply with the preemptions would be small, but CBO could not estimate the cost of verifying work eligibility and new requirements. The costs are dependent on how the regulations are established by the federal government, making it is difficult to estimate (CBO 2007b).

\section{Administrative Feasibility}

While state and local governments would be prohibited from enforcing immigration laws, they would be required to participate in the electronic employment verification system (EEVS) for new hires (Migration Policy Institute 2009). It is unclear how regulations established by the federal agencies would impact its implementation on these levels.

As there are implementation problems with the current system, administrative feasibility would be a challenge for the federal government. Revamping the immigration system would be a complex and daunting task, including but not limited to benefit programs, a legalization program, visa reform, and enforcement improvements.

\section{Political Feasibility}

The Obama Administration stated that comprehensive immigration reform would be a top priority, and in June 2009 the White House convened a meeting with members of Congress to discuss reform (Wasem 2010). While the president pledged to work on fixing the "broken immigration system" during the 2010 State of the Union address, the issue was placed on the backburner as the president and Congress turned their focus to health care reform this past year. The president reiterated this commitment in his 2011 State of the Union speech, acknowledging the plight of unauthorized students and calling for illegal immigration to be addressed once and for all (White House 2011).

It remains to be seen if immigra- tion reform will be addressed in the 112th Congress with the recent defeat of the DREAM Act in the previous Congress. It is very difficult to separate the debate between immigration reform and the DREAM Act because the former encompasses the latter. Before the vote, Representative Smith was poised to bring up reform because there are conservative freshmen members supportive of his position in the new Congress (Aujla 2010). In the other chamber, Senator Leahy, Chairman of the Judiciary Committee (which has jurisdiction over immigration), believes the focus should be on comprehensive reform that is backed by both parties (O'Connor 2010). Ultimately, immigration reform is a polarizing issue, and with both parties mindful of the 2012 presidential election, it is likely that the matter will not be addressed in the next two years. Given these factors, the political feasibility for CIR ASAP is low.

\section{Sustainability}

The CIR ASAP Act provides longterm solutions to the unauthorized immigrant student population. Unlike the DREAM Act, the comprehensive reform bill establishes visa programs for future unauthorized populations. In addition, the CIR ASAP Act does not ignore a population with an arbitrary cut-off date; those eligible under the legalization program would only have to be present in the United States at the time of enactment, as opposed to five years prior to its passage under the DREAM Act (Migration Policy Institute 2009). Because it provides a path to legalization, removes potential barriers to higher education funding, and addresses the future populations that enter the country, the sustainability of the CIR ASAP Act is high.

\section{Alternative 3: Immigrant Education}

Services in Community Colleges

Given the barriers in passing federal legislation, state alternatives should be considered as possible solutions to im- 
prove the educational attainment of the unauthorized student population. It is relevant to note that these alternatives cannot address the legal status of this population; however, initiatives on the local level can be taken to improve their educational status. Moreover, states have an interest in addressing the plight of this population. As mentioned earlier, the unauthorized population is employed primarily in low-skilled, low-wage jobs, and 32 percent of unauthorized children are in poverty. Investing in this population's education can benefit state and local governments because a highly educated workforce can contribute more to the economies of these communities. Therefore, it is in the best interests of the states to support this population and improve their educational attainment in the long run.

One state alternative involves implementing a Florida program, the Global Education Center, that improves the educational attainment of the unauthorized population, and establishing similar programs in other states. The Center is a one-stop education and resource information center for immigrants at Palm Beach State College. The Community College Consortium for Immigrant Education, an organization of community colleges committed to expanding the range of quality of programs and services for immigrant students, identified the Center as a promising practice in immigrant education (Community College Consortium for Immigrant Education 2010).

The Center provides immigrants scholarships to attend college, English as a Second Language (ESL) classes, acculturation workshops, and referrals to receive community services. The program targets new immigrants with varying degrees of education and unauthorized students in the public school system. Students must be enrolled in an educational program at the college, demonstrate a financial need, maintain a GPA of 2.0, meet with an advisor, follow an improvement plan if they fall short in their performance, complete community service hours, and serve as a peer mentor. Health care, legal, child care, transportation, employment, and financial literacy assistance are also offered. The Center has partnered with communitybased organizations, local elected officials, local businesses, and school districts to provide services and outreach to this population. Furthermore, the Center is privately funded (Community College Consortium for Immigrant Education 2010).

The results of the program have been promising since its establishment three years ago. The Center has registered 1,260 students representing more than 55 different countries and granted scholarships to 132 students for degree or certificate programs and ESL courses. During the 2009-2010 school year, 14 students completed associate degrees and moved on to complete a bachelor's degree, and three students received vocational certificates. Forty-six adults have completed ESL courses and are continuing their education or are preparing for professional career licensing. The Center also provided integration workshops, immigrant information sessions, and outreach in partnership with Palm Beach County schools' multilingual and migrant education programs. Furthermore, the program also partnered with the Commissioners of the City of Lake Worth to open the Lake Worth Resource Center (LWRC). The LWRC provides "ready-to-work" labor for employers by offering carpentry training, cake decorating, and office support courses (Community College Consortium for Immigrant Education 2010). As a promising alternative to improve the status of the unauthorized population in all states, the following is an analysis based on the established criteria.

\section{Effectiveness}

This alternative has the potential to address the 40 percent of unauthorized immigrants aged 18 to 24 that have less than a high school diploma. In comparison, only eight percent of US- 
born students the same age do not have a high school degree (Passel and Cohn 2009). Targeting community colleges is logical since one in four community college students is an immigrant or the child of an immigrant, and immigrants are 20 percent more likely than natives to begin their higher education at a community college (Conway 2010; Gonzalez 2010). This can be explained in part by the scheduling flexibility that community college offers, enabling these students to work full-time and contribute to their family's income (Oseguera 2010).

This alternative has the potential to improve the educational attainment of the unauthorized population because it addresses the limited English proficiency of this population. According to the Migration Policy Institute, lack of English proficiency is a barrier to the unauthorized population's educational attainment (Batalova and McHugh 2010). The National Council of State Directors of Adult Education reports that about 160,000 students were on waiting lists for 986 local ESL programs in all 50 states during the 2009-2010 school year. This number has doubled in just one year, up from 800,000 potential learners on the waiting list in 710 programs in $2008(\mathrm{Na}-$ tional Council of State Directors of Adult Education 2010). By offering ESL classes, this alternative could help meet this need and increase the educational attainment of this population.

While this alternative does not increase the number of students that can access financial aid, it does address the affordability of higher education. Because this option focuses upon community colleges, which are less expensive than fouryear institutions, and provides stipends and scholarships to students, this alternative makes higher education more affordable for those that participate in the program (Oseguera 2010). As mentioned earlier, this option does not provide access to the workforce with legal work authorization. Being undocumented is an obstacle to most high-skilled jobs and deters the unauthorized from seeking higher education. The risk of being deported, if found out, may discourage them from incurring investments like education.

\section{Cost}

While the Global Education Center was initially funded with a $\$ 1$ million donation, it is not feasible for all states to rely on private donations to implement this program. States would bear a significant share of the cost to implement this program at their community colleges. It is important to note that most ESL programs rely on federal grants and private fundraising, and federal funding can provide a share of the cost by covering ESL classes (Dryden-Peterson 2007). In FY 2010, the US Department of Education received $\$ 628$ million in appropriations for adult basic and literacy education state grants (US Department of Education 2011). While the costs to states would be high, the costs to the federal government would be low relative to its estimated $\$ 1.4$ trillion in discretionary spending in 2011 (CBO 2011).

\section{Administrative Feasibility}

States have the capacity to implement this alternative as it operates in existing community college institutions. It is possible for advisors and staff for the program to be shared with other departments. In addition, community colleges across the country are already implementing similar programs that provide ESL classes and services to immigrant students. For example, the state of Washington's Integrated Basic Education and Skills Training (I-BEST) Program combines vocational classes with ESL classes and was implemented in all 34 of the state's community and technical colleges (Spence 2010).

\section{Political Feasibility}

The political feasibility of this alternative is low due to state fiscal conditions. States will encounter significant 
challenges in FY 2012 and FY 2013 as revenues are projected to remain well below their 2008 levels, and emergency funding provided by the American Recovery and Reinvestment Act of 2009 will no longer be available. Although not all state budget offices have completed forecasts at the time of publication, thus far 23 states are reporting $\$ 40.5$ billion in budget gaps for FY 2012, and 17 states are reporting \$40.9 billion in budget gaps for FY 2013. In order to reduce or eliminate budget gaps, states increased user, higher education, court, and motor vehicle fees, and implemented layoffs and furloughs (National Governors Association and National Association of State Budget Officers 2010).

The current economic climate has also impacted community college enrollment. Unfortunately, 35 states cut higher education budgets in 2010, and 31 will cut them in 2011, according to survey data from the National Association of State Budget Officers (2010). For example, in May 2010, New York's community colleges stopped accepting applications for the fall semester and added students to a wait list, while California's community colleges turned away 140,000 students (Whoriskey 2010). Those shortages are expected to worsen in 2012 when federal stimulus money that had plugged holes in state budgets is no longer available.

The political climate has also turned hostile towards this population in some states. Legislators have introduced bills targeting the birthright citizenship of unauthorized children, and candidates have singled out unauthorized students as a financial burden (Billeaud 2011; Ferriss 2010). Using public monies and resources to assist the unauthorized population would be seen unfavorably given the fiscal situation of states and the rhetoric toward the unauthorized population.

\section{Sustainability}

This alternative has the potential to increase the number of unauthorized students that pursue a higher education thanks to outreach efforts. A higher education can improve labor market opportunities and even help change the immigration status of the undocumented in a number of ways: by improving their labor market skills and employability in the US economy, by providing them with skills to undertake jobs for which employers can sponsor undocumented persons for temporary legal visas, and by opening new paths to legalization through marriage as college education improves marriageability and increases interethnic marriage (Spence 2010; Goldstein and Kenney 2001; Qian 1997). However, these are only possibilities and are not viable solutions for all. Pursuing a college education is a large investment for an unauthorized individual and, despite having a degree, that individual still does not have legal authorization to work.

\section{Conclusions and Recommendation}

This paper examines the current plight of the unauthorized student population and the challenges they encounter in becoming productive members of society. Unauthorized students like Erick Huerta face significant barriers in pursuing a higher education due to the fear of revealing their status, the inability to work legally, the high cost of education relative to the low income earned in their households, and federal and state laws that increase the cost of tuition. These individuals are pushed into the underground economy without legal status. A higher education and legal status would allow these individuals to earn higher incomes, lead healthier lives, and fully contribute to society.

The nation has an economic interest in seeing this immigrant population succeed because low-wage and low-skilled jobs will not sustain this population or the nation's economy. With the baby boom generation retiring and heightening competition in the global economy, immigrants will be key in growing the nation's workforce. The cost of not addressing this 
situation is high because state and local governments have already invested in the primary and secondary education of these individuals, and the federal government is spending about $\$ 15$ billion on inefficient immigration enforcement and not addressing the economic pull to work in the US (Hanson 2009). Given these factors, it is in the nation's economic self-interest that this population obtain a higher education and succeed in the labor market.

An analysis of alternatives to address the status of the unauthorized population included three possible options. Upon first glance, the DREAM Act is a feasible policy but deeper examination reveals otherwise. The policy fared well under effectiveness, cost, and administrative feasibility. Yet it did not fare well in terms of political feasibility and sustainability. The policy, as it is currently written, creates a sub-population of unauthorized immigrants that have not been in the country longer than five years or are older than the age of 30. In essence, the bill excludes individuals that arrived in the United States as children but do not qualify under the bill's age and residency requirements. As a result, the DREAM Act does not reach all unauthorized immigrants that came to this country as children. What will happen to this sub-population of students? They will continue to experience difficulties obtaining a higher education and will not contribute their skills and talents to society. In the future, the same questions will arise about legalizing this sub-population. The United States made this mistake in the past with the 1986 Immigration Reform and Control Act (IRCA), which legalized 2.7 million unauthorized immigrants; unfortunately, it did not provide a legal path for low-skilled workers to enter the country. As a result, IRCA temporarily decreased the number of unauthorized immigrants, but the pull of the US labor market continued to attract individuals to come to the country illegally (Griswold 2010). Almost 25 years later, the nation is still trying to address this problem. IRCA's shortcomings demonstrate a similar flaw in the DREAM Act. A legalization program and reforming the visa process for lowskilled workers is necessary in order to make the DREAM Act sustainable.

While the federal alternatives most likely will not be addressed in the 112th Congress, in the interim states can take action by reaching out to this population and encouraging the pursuit of a higher education in the short term. But given the current economic climate and lack of funds for education in general, states do not have the capacity to pursue this alternative. Until the economy improves for states, private donations and foundation grants may be the most viable avenue in improving this alternative and increasing chances to implement this program at the state level. Community colleges can pursue partnerships as a form of cost-sharing in providing services to immigrants. For example, Westchester Community College in New York offers English classes to day laborers in collaboration with Neighbors Link, a local nonprofit organization that provides social services to these individuals (Gonzalez 2010). Nonetheless, states are unable to address the legal status of the unauthorized population in the long run. Providing the opportunity to the unauthorized student population to work legally is the key to addressing the plight of this population.

Based on this analysis, comprehensive immigration reform has the greatest potential to address the deficiencies in the policies toward unauthorized students and unauthorized immigrants in general. In the long run, this alternative has the potential to increase the number of students that can legally work and access federal financial aid and in-state tuition. Although costly, it is the only alternative that addresses the entire unauthorized population because it creates a legalization program and visa program that can systematize the economic pull of working in the United States. Because the political environment is dynamic, the 
feasibility of immigration reform being addressed in Congress or by the administration can become more favorable. When the time is ripe, the CIR ASAP Act or a similar immigration reform bill could be the best policy in addressing the unauthorized student population and the unauthorized population of the United States as a whole. The American Dream for unauthorized students like Erick Huerta will be on hold until that time comes.

\section{References}

Associated Press. 2010. "White House: Obama won't give up on DREAM Act." December 21. http://www.google.com/hostednews/ap/article/ALeqM5h1TFarDuCbdRtZSWjzZYEs 3eBGQ?docId=922bo23e7d454484949082deee7bffff.

Aujla, Simmi. 2010. "New GOP-ers tough on immigration?" Politico, November 1. http://www.politico.com/news/stories/1110/44512.html.

Bardach, Eugene. 2009. A Practical Guide for Policy Analysis: The Eightfold Path to More Effective Problem Solving. Washington, DC: CQ Press.

Batalova, Jeanne and Margie McHugh. 2010. "DREAM vs. Reality: An Analysis of Potential DREAM Act Beneficiaries." Prepared by the Migration Policy Institute, Washington, DC. Accessed January 5, 2011. http://www.migration policy.org/ pubs/DREAM-Insight-July2010.pdf.

Berman, Russell. 2010. "Pelosi: Immigration reform requires 'presidential leadership'." The Hill, April 29. http://thehill.com/blogs/blog-briefing-room/news/95199pelosi-immigration-reform-will-require-presidential-leadership-and-congres sional-appetite.

Billeuad, Jacques. 2011. "Arizona legislation targets automatic citizenship.” Associated Press, January 28. http://finance.yahoo.com/news/Arizona-legislationtargets-apf-2838201953.html? $\mathrm{x}=\mathrm{0} \& . \mathrm{v}=1$.

Bruno, Andorra, Karma Ester, Chad C. Haddal et al. 2010. "Immigration Legislation and Issues in the 111th Congress, R40848." Prepared by the Congressional Research Service, Washington, DC.

Bruno, Andorra. 2010. "Unauthorized Alien Students: Issues and "DREAM Act" Legislation, RL33863." Prepared by the Congressional Research Service, Washington, DC.

College Board. 2010. “Trends in College Pricing 2010.” Accessed June 28, 2010. http:// trends.collegeboard.org/college_pricing/.

Community College Consortium for Immigrant Education. 2010. "Best Practices in Immigrant Education.” Accessed February 9, 2010. http://www.cccie.org/imag es/stories/best_practices_Palm_Beach_State_College.pdf.

Conger, Dylan and Colin C. Chellman. 2011. "The Educational Experiences and Outcomes of Undocumented College Students." Prepared for The Association for Education Finance and Policy annual meeting, March 2011, Seattle, Washington.

Congressional Budget Office. 2007a. "The Impact of Unauthorized Immigrants on the Budgets of State and Local Governments." Accessed March 7, 2011. http:// www.cbo.gov/doc.cfm?index $=8711 \& z z z=36123$. 
- - 2007b. "Senate Amendment 1150 to S. 1348, The Comprehensive Immigration Reform Act of 2007.” Accessed June 26, 2010. http://cbo.gov/doc. cfm? index $=8179 \&$ type $=0$.

-—-. 2011. "The Budget and Economic Outlook: Fiscal Years 2011 to 2021." Accessed February 8, 2011. http://www.cbo.gov/ftpdocs/120xx/doc12039/0126_FY 2011Outlook.pdf.

-—-. 2010. "H.R. 6497 Development, Relief, and Education for Alien Minors Act of 2010: As introduced on December 7, 2010.” Accessed December 20, 2010. http://cbo.gov/doc.cfm ?index=12015.

Conway, Kathleen. 2010. "Educational Aspirations in an Urban Community College: Differences Between Immigrant and Native Student Groups.” Community College Review 37 (3): 209-243.

Cutler, David M. and Adriana Lleras-Muney. 2008. "Education and health: evaluating theories and evidence." In Making Americans Healthier: Social and Economic Policy as Health Policy, edited by R. Schoeni, 29-6o. New York: Russell Sage Foundation.

Dee, Thomas S. 2004. “Are there civic returns to education?” Journal of Public Economics 88: 1697-1720.

Dryden-Peterson, Sarah. 2007. "Adult English Language Instruction in the United States: Determining Need and Investing Wisely." Harvard Educational Review 77(4): 515-521.

Emery, Theo. 2010. "Immigration Overhaul Likely to Remain Stalled in 2011." Congressional Quarterly, November 3.

-—-. 2010. "Controversial King Denied Top Immigration Slot.” Congressional Quarterly, January 7.

Ewing, Walter. 2009. "Critical Care: The Role of Immigrant Workers in U.S. health care." Prepared by the Immigration Policy Center, Washington, DC. Accessed December 20, 2010. http://www.immigrationpolicy.org/just-facts/criticalcare-role-immigrant-workers-us-health-care.

Feder, Jody. 2010. "Unauthorized Alien Students, Higher Education, and In-state Tuition Rates: A Legal Analysis, RS22500.” Prepared by the Congressional Research Service, Washington, DC.

Ferriss, Susan. 2010. "Illegal immigrants less than 1 percent of California college enrollment." The Sacramento Bee, April 1. http://www.sacbee. com/2010/04/01/2648006/illegal-immigrants-less-than-1.html.

Fix, Michael, Margie McHugh, Aaron Matteo Terrazas et al., 2008. "Los Angeles on the Leading Edge: Immigration Integration Indicators and Their Policy Impli cations.” Prepared by the Migration Policy Institute, Washington, DC. Accessed May 29, 2010. http://www.migrationpolicy.org/pubs/NCIIP_Los_Angeles_ on_the_Leading_Edge.pdf.

Flores, Stella M. 2010. "State Dream Acts: The Effect of In-State Resident Tuition Policies and Undocumented Latino Students." The Review of Higher Education 33 (2): 239-283.

Goldstein, Joshua R. and Catherine T. Kenney. 2001. "Marriage Delayed or Marriage Forgone? New Cohort Forecasts of First Marriage for U.S. Women.” American Sociological Review 66 (4): 506-519.

Gonzalez, Jennifer. 2010. "Community Colleges Build Innovative Programs That Fit Immigrants' Needs." Chronicle of Higher Education, February 28.

Griswold, Daniel. 2010. "Comprehensive Immigration Reform: What Congress and the President Need to Do to Make it Work.” Albany Government Law Review 3 (1). 
Hanson, Gordon H. 2009. "Economics and policy of illegal immigration in the United States.” Prepared by the Migration Policy Institute, Washington, DC. Accessed May 29, 2010. http://www.migrationpolicy.org/pubs/Hanson-Deco9.pdf.

Huerta, Erick. 2010. "The double life of an undocumented student." Zocalo Public Square, December 5. Accessed January 6, 2011. http://zocalopublicsquare.org/ thepublicsquare/2010/12/05/the-double-life-of-an-undocumented-stu dent/read/nexus/.

Immigration Policy Center. 2009. "Summary of the Comprehensive Immigration Reform for America's Security and Prosperity Act of 2009.” Last modified December 15. http://www.immigration policy.org /just-facts/summary-comprehensive-immigration-reform-americas-security-and-prosperity-act-2009.

Irwin, Lewis G. 2003. The Policy Analyst's Handbook: Rational Problem Solving in a Political World. London, England: M.E. Sharpe.

Kaushal, Neeraj. 2008. "In-State Tuition for the Undocumented: Education Effects on Mexican Young Adults.” Journal of Policy Analysis and Management 27 (4): 771-792.

Kiely, Kathy. 2007. "Children caught in the immigration crossfire; Bill stirs new debate over a generation lost "in limbo." USA Today, October 8.

Lee, Youngro. 2006. "To Dream or Not to Dream: A Cost-Benefit Analysis of the Development, Relief, and Education for Alien Minors (DREAM) Act." Cornell Journal of Law and Public Policy 16: 231-258.

Library of Congress. 2010a. "Bill text 111th Congress (2009-2010) H.R. 5281." Accessed December 20, 2010. http://thomas.loc.gov/cgi-bin/t2GPO/http:// www.gpo.gov/fdsys/pkg/BILLS 111hr5281eah/pdf/BILLS-111hr5281eah.pdf.

- - . 2010b. "Bill summary \& status 111th Congress (2009-2010) H.R. 1751." Accessed June 1, 2010. http://thomas.loc.gov/cgi-bin/t2GPO/http://www.gpo.gov/fd sys/pkg/BILLS-111hr1751ih/pdf/BILLS-111hr1751ih.pdf.

-—-. 2010c. "Bill summary \& status 111th Congress (2009-2010) H.R. 4321.” Accessed December 22, 2010. http://thomas.loc.gov/cgi-bin/t2GPO/http:// www.gpo.gov/fdsys/pkg/BILLS-111hr4321ih/pdf/BILLS-111hr4321ih.pdf.

Lochner, Lance and Enrico Moretti. 2004. "The Effect of Education on Crime: Evidence From Prison Inmates, Arrests, and Self-reports.” American Economic Review 94 (1): 155-89.

Lowell, B. Lindsay, Gelatt, Julia, and Jeanne Batalova. 2006. "Immigrants and Labor Force Trends: The Future, Past and Present.” Prepared by the Migration Policy Institute, Washington, DC. Accessed February 9, 2011. http://www. migra tionpolicy.org/ITFIAF/TF17_Lowell.pdf.

Migration Policy Institute. 2006. "New Estimates of Unauthorized Youth Eligible for Legal Status Under the DREAM Act.” Accessed June 1, 2010. http://www.mi grationpolicy.org/pubs/Backgrounder1_Dream_Act.pdf.

- - . 2009. "Side-by-Side Comparison of 2006 and 2007 Senate Legislation and 2009 CIR ASAP Bill.” Accessed June 1, 2010. http://www.migrationpolicy.org/ pubs/CIRASAPsidebyside.pdf.

Migration Policy Institute. 2010."MPI Updates National and State-Level Estimates of Potential DREAM Act Beneficiaries.” Accessed December 22, 2010. http:// www.migrationpolicy.org/pubs/DREAM-Update-December2010.pdf.

Morse, Ann and Kerry Bimbach. 2010. "In-State Tuition and Unauthorized Immigrants Students.” Prepared by the Conference of State Legislatures, Washington, DC. Accessed May 28, 2010. http://www.ncsl.org/ default.aspx?tabid=13100.

National Conference of State Legislatures. 2010. "Undocumented Student Tuition: 
Overview.” Accessed December 20. http://www.ncsl.org/default. aspx?tabid=12876.

National Council of State Directors of Adult Education. 2010. "Adult Student Waiting List Survey.” Accessed January 7. http://www.naepdc.org/publica tions/2010\%20Adult\%20Education\%20Waiting\%20List\%20Report.pdf.

National Governors Association and National Association of State Budget Officers. 2010. "Fiscal Survey of the States: An Update on State Fiscal Conditions." Accessed January 6, 2011. http://www.nasbo.org/LinkClick.aspx?fileticket=C6q1 M3kxaEY\%3d\&tabid=38.

Nicholas, Peter. 2010.“Obama Administration poised to challenge Arizona law.” Los Angeles Times, June 26. http://www.latimes.com/news/nationworld/nation/ la-na-arizona-law-20100626,0,2047818.story.

O'Connor, Kevin. 2010. "Leahy on the borderline in immigration debate." Times Argus, June 6. http://www.timesargus.com/article/RH/20100606/ NEWS/100609967/o/SPORTS.

Osegura, Leticia, Stella M. Flores, and Edelina Burciaga. 2010. "Documenting Implementation Realities: Undocumented Immigrant Students in California and North Carolina.” Journal of College Admission (Winter 2010): 37-43.

Passel, Jeffrey S. and D'Vera Cohn. 2009. "A Portrait of Unauthorized Immigrants in the United States.” Prepared by the Pew Hispanic Center, Washington, DC. Accessed May 28, 2010. http://pewhispanic.org/reports/report.php? Repor tID $=107$.

Passel, Jeffrey S. \& D’Vera Cohn. 2010. “U.S. Unauthorized Immigration Flows Are Down Sharply Since Mid-Decade.” Prepared by the Pew Hispanic Center, Washington DC. Accessed December 22, 2010. http://pewhispanic.org/ re ports/report.php?ReportID=126.

Plyler v. Doe, 457 U.S. 202 - Supreme Court 1982.

Qian, Zhenchao. 1997. "Breaking the Racial Barriers: Variations in Interracial Marriage Between 1980 and 1990.” Demography 32 (2): 263-276.

Spence, Robin. 2010. “Sound Investments: Building Immigrants' Skills to Fuel Econom ic Growth. Economic Mobility Corporation.” Accessed January 8, 2011. http:// economicmobilitycorp.org/uploads/mobility-sound_investments.pdf.

US Census Bureau. 2010. "Income, Poverty, and Health Insurance Coverage in the United States: 2009.” Accessed March 31, 2011. http://www.census.gov/ prod/2010pubs/p60-238.pdf.

US Citizenship and Immigration Services. 2011."Check filing fees.” Accessed March 11, 2011. http://www. uscis.gov/portal/site/uscis/menuitem.eb1d4c2a3e5b9ac 89243c6a7543f6d1a/?vgnextoid=b1ae408b1c4b3210VgnVCM10000ob92ca6o aRCRD\&vgnextchannel=b1ae408b1c4b3210VgnVCM100ooob92ca6oaRCRD.

-—-. 2008. “CIS Ombudsman Annual Report 2008.” Accessed June 28, 2011. http:// www.dhs.gov/xlibrary/assets/CISOMB_Annual_Report_2008.pdf

-—-. 2009. “CIS Ombudsman Annual Report 2009.” Accessed June 27,2010. http:// www.dhs.gov/xlibrary/assets/CISOMB_Annual_Report_2009.pdf

US Department of Education. 2010. "Department of Education Fiscal Year 2010 Congressional Action.” Accessed January 8, 2010. http://www2.ed.gov/about/ overview/budget/ budget10/10action.pdf.

US House of Representatives. 2010."Final Vote Results for Roll Call 625.”Accessed December 22. http://clerk.house.gov/evs/2010/roll625.xml.

Vedantum, Shankar. 2010. "Defeat of immigration measure reveals failed White House strategy, advocates say.” Washington Post, December 18. 
Wasem, Ruth E. 2010. "Immigration Reform Issues in the 111th Congress, R40501." Prepared by the Congressional Research Service, Washington, DC.

White House. 2011."Remarks by the President in the State of Union Address." Accessed January 28. http://www.whitehouse.gov/the-press-office/2011/o1/25/ remarks-president-state-union-address.

Whoriskey, Peter. 2010. "Workers seek new skills at community colleges, but classes are full.” Washington Post, November 26. http://www.washingtonpost.com/ wpdyn/content/article/2010/11/26/AR2010112605087_pf.html.

8 U.S.C. $\S 1227.2010$. Deportable aliens.

8 U.S.C. $\S 1324$ a. 2010. Unlawful employment of aliens.

8 U.S.C. $§ 1623$. 2010. Limitation on eligibility for preferential treatment of aliens not lawfully present on basis of residence for higher education benefits.

Jennifer Javier is a second year Master of Public Administration student at The George Washington University, concentrating in public management. She earned a BA at the University of California, Los Angeles with a major in sociology and minors in public policy and Asian American studies. Prior to graduate school, she worked for a congressman conducting constituent services and fieldwork for four years. Her experiences working with immigrants and growing up in an immigrant family inspired this paper.

The author thanks editors Rachel Brody, Alicia Mazzara, Andrea Leung, and Kaitlin Welborn for their valuable comments, support, and encouragement. The author would also like to thank Dr. Donna Infeld for recommending the paper for publication, and Professor Leighton Ku and Dr. Dylan Conger for their insights. Finally, the author would like to thank her fiancé, Brian Plaskow, and her family for their unconditional support. 